\title{
Lack of effects of recombinant human GH on spermatogenesis in the adult cynomolgus monkey (Macaca fascicularis)
}

\author{
Ingrid Sjögren ${ }^{1,4,5}$, Sven Ekvärn ${ }^{1}$, Ulrich Zühlke ${ }^{2}$, Friedhelm Vogel ${ }^{2}$, Walter Bee ${ }^{2}$, Gerhard F Weinbauer ${ }^{3}$ and \\ Eberhard Nieschlag ${ }^{3}$ \\ ${ }^{1}$ Toxicology, Pharmacia \& Upjohn, Stockholm, Sweden, ${ }^{2}$ Covance, Münster, Germany, ${ }^{3}$ Institute of Reproductive Medicine of the University, Münster, \\ Germany, ${ }^{4}$ Department of Anatomy and Histology, Faculty of Veterinary Medicine, Swedish University of Agricultural Sciences, Uppsala, Sweden and \\ 5 present address: Novo Nordisk A/S, Denmark \\ (Correspondence should be addressed to S Ekvärn, Toxicology, Pharmacia E Upjohn, S-112 87 Stockholm, Sweden)
}

\begin{abstract}
Objective: The effects on male reproductive parameters after 1 year of treatment with recombinant human GH to the cynomolgus monkey were investigated.

Design: Twenty-four male cynomolgus monkeys were given daily subcutaneous doses of 0 (vehicle) $(n=7), 0.4(n=5), 2.0(n=5)$ and $10.0(n=7) \mathrm{IU} / \mathrm{kg}$ bodyweight for 52 weeks. At completion of the treatment period two control and two high-dose animals were left for a 12-week treatment-free period. Methods: Before and during the treatment period and during the recovery period, sperm analyses, testicular volume measurements and hormone analyses of prolactin (PRL), LH, FSH, testosterone and IGF-I in serum, and analysis of serum antibodies against human GH were performed. Testicular morphology was monitored by biopsies, predose and on day 15 of the study, and with light microscopy on organ samples collected at time of death, at the end of the treatment, and during recovery periods respectively.

Results: Of all studied parameters, alterations were observed only in serum levels of IGF-I and PRL. IGF-I showed a dose-dependent increase throughout the treatment, with a normalisation during the treatment-free period. PRL decreased significantly in animals given $10.0 \mathrm{IU} / \mathrm{kg}$ per day from week 14 of treatment and throughout the study but with a normalisation upon cessation of treatment. Spermatogenesis, as judged from semen analysis, testicular volume measurements and testicular morphology was not affected.

Conclusion: This controlled preclinical study demonstrates that high doses of human GH do not alter male reproductive parameters in a non-human primate model.
\end{abstract}

European Journal of Endocrinology 140 350-357

\section{Introduction}

The role of growth hormone $(\mathrm{GH})$ in male reproduction has been elucidated in recent years. It is obviously of importance for normal pubertal development and subsequent fertility (1). The development of the genital organs is poor in GH-deficient boys and administration of $\mathrm{GH}$ increases the growth of the genitalia $(2,3)$. In children with dwarfism due to resistance to the action of GH (Laron-type dwarfism) puberty is delayed (4). Data from experimental animal studies are in line with those clinical data. The GH-deficient dwarf mouse has reduced testicular weight, seminiferous tubular diameter and germ cell number; however, with GH administration during the postnatal period these parameters can be normalised (5). In the prepubertal boar exogenous $\mathrm{GH}$ increased Sertoli cell size, tubular lumen formation and initiated spermatogenesis earlier than in controls (6). Reduced seminal fluid volume and total sperm number/ ejaculate compared with reference groups were found in patients with isolated GH deficiency (7). Treatment with GH for 4 months did not improve semen quality, probably due to too short a treatment period. However, in some infertile patients with hypogonadotrophic hypogonadism Shoham et al. (8) observed that co-treatment with gonadotrophins and GH resulted in increased serum testosterone concentrations and a normalisation of sperm parameters. If gonadotrophins were given alone, these effects were not seen.

In man, an effect of GH on Leydig cell function has been demonstrated in pubertal boys (9). The postulated mechanism for the effect of $\mathrm{GH}$ on testicular function is an increase of local insulin-like growth factor-I (IGF-I) production which leads to an augmentation of the follicle-stimulating hormone (FSH) acting directly on Sertoli and indirectly on Leydig cells. Studies in animals and man have elucidated the interaction between $\mathrm{GH}$ and sex steroids $(10,11)$.

In studies performed as a part of the safety documentation, high doses of human (h) GH have been given to 
normal intact animals. In the monkey and the rat, hGH has been shown to have few adverse effects $(12,13)$ after up to 3 months of treatment. However, in the male dog severe testicular alterations and reduced plasma levels of testosterone, luteinizing hormone (LH) and prolactin (PRL) have been observed in preclinical safety studies after 3-4 weeks of treatment (14).

To evaluate possible effects on spermatogenesis of $\mathrm{hGH}$ in the cynomolgus monkey, male reproductive parameters were carefully monitored before and during the treatment period and at the end of a 12-week recovery period in this 1 year preclinical safety study. The reproductive system of humans and Old World non-human primates share many similarities. Hence, several macaque species were tested in studies of reproductive physiology and reproductive toxicology and were proved to be appropriate preclinical animal models $(15,16)$. The doses used were 10-250 times the recommended therapeutic dose in adult $\mathrm{GH}_{-}$ deficient patients and 4-100 times the doses used in GH-deficient children.

\section{Materials and methods}

\section{Animals and treatment}

Twenty-four adult male cynomolgus monkeys (Macaca fascicularis) weighing between 3.7 and $5.4 \mathrm{~kg}$ at the start of dosing were used for the study. Although the precise age of the animals was unknown, they were considered to be sexually mature at the start of the treatment, due to historical data regarding the relationship between body weight and age.

The monkeys were divided into four groups and treated with recombinant human (rh) GH (Genotropin; $12 \mathrm{IU}$; Pharmacia AB), or vehicle (glycine/phosphatebuffered solution). The doses were 0 (vehicle) $(n=7)$, $0.4(n=5), 2.0(n=5)$ and $10.0(n=7) \mathrm{IU} / \mathrm{kg}$ per day corresponding to $0,0.13,0.65$ and $3.23 \mathrm{mg} / \mathrm{kg}$ per day respectively.

The animals were treated once daily in the morning for 52 weeks by subcutaneous bolus injections on the back. The administered dose volume $(2 \mathrm{ml} / \mathrm{kg})$ was divided into two equal doses which were injected on the same occasion at two different sites. Six sites were used and these were alternated. Five animals/group were killed after the treatment period, whereas two animals in the control and high-dose groups, respectively, were given a 12-week treatment-free period before being killed. The monkeys were housed individually in stainless steel cages in rooms maintained at a temperature of $20-25^{\circ} \mathrm{C}$ and a relative humidity of $40-$ $70 \%$. They were exposed to artificial light for $12 \mathrm{~h}$ (0600-1800 h) during a 24-h light/darkness cycle and fed twice daily with about $70 \mathrm{~g} / \mathrm{animal}$ of a pelleted diet. Additional fruit supplement was also given. Food was withdrawn overnight prior to blood sampling. Maintenance and experimentation with animals was performed in accordance with the German Law for the Care and Use of Laboratory Animals.

\section{Analyses, measurements and morphological examinations}

Individual body weight was recorded before initiation of treatment and then weekly throughout the treatment and recovery periods and on the day of necropsy.

Sperm analysis was performed three times before the treatment period at intervals of at least 4 days, in weeks $13,26,39$ and 52 and at the end of the treatment-free period. Ejaculates were obtained by rectal probe stimulation under light anaesthesia with ketamine hydrochloride (Ketavet; Parke-Davis, Germany). The weight and volume of each ejaculate was recorded and the coagulum - if present - was digested using a $2 \%$ trypsin solution. The sperm number was determined in both exudate and coagulum using a haematocytometer and expressed as spermatozoa $\times 10^{6} /$ ejaculate. Sperm motility was evaluated microscopically in the exudate. Sperm morphology was assessed from Papanicolaoustained exudate smears according to the WHO guidelines (17). Testicular size measurements using an adjustable square were carried out in a blinded fashion twice before the start of treatment, and in weeks 13, 28, 40 and 52, and at the end of the treatment-free period. Unilateral surgical testicular biopsy was performed under sedation once before the treatment period and on day 15 of the study on three animals from the control and high-dose groups and on two animals from the low- and intermediate-dose groups. Biopsies were performed as described earlier (18). The biopsy material was fixed in $5.25 \%$ glutaraldehyde in $0.067 \mathrm{~mol} / \mathrm{l}$ sodium cacodylate buffer ( $\mathrm{pH} 7.4$ ) and embedded in Epon. Semithin sections (about $0.5 \mu \mathrm{m}$ ) were stained with toluidine blue and evaluated by light microscopy.

Blood samples for hormone analyses were collected from the brachial vein in the morning during the pretest period and before dosing in weeks 14, 27, 39/40 and 52 and after the recovery period for serum analysis of IGF-I, PRL, testosterone, FSH and LH. However, the week-52 samples for LH and testosterone for the animals in the groups given 0.4 and $2.0 \mathrm{IU} / \mathrm{kg}$ per day respectively were not analysed. Blood for analysis of IGF-I was also sampled on days 5 and 10. For gonadotrophins and testosterone, blood was sampled at the same time in the morning for 3 successive days on each occasion. In the Figures median values are given. The following assays were used: IGF-I, a competitive RIA following acid-ethanol treatment, detection limit $20 \mu \mathrm{g} / \mathrm{l}$, coefficient of variation 3.1\% (intra-assay) and 10\% (interassay) (19); PRL, an RIA, detection limit $2 \mathrm{ng} / \mathrm{ml}$, coefficient of variation 3.2\% (intra-assay) and 7.5\% (interassay) (Testpack DPC; Hermann Biermann $\mathrm{GmbH}$ Diagnostica); testosterone, an RIA following ether extraction, detection limit $0.2 \mathrm{nmol} / \mathrm{l}$, coefficient of variation $8.5 \%$ (intra-assay) and $13.0 \%$ (interassay) 
(20); FSH, an RIA, detection limit $0.1 \mathrm{mg} / \mathrm{l}$, coefficient of variation $8.4 \%$ (intra-assay) and $10.8 \%$ (interassay) (21); LH, an in vitro mouse Leydig cell bioassay, detection limit $2.7 \mathrm{U} / \mathrm{l}$, coefficient of variation $13.1 \%$ (intra-assay) and 16.9\% (interassay) (22).

Blood samples were collected from all animals during the pre-test period, and in weeks 13 and 26, and at necropsy for determination of serum antibodies against hGH which was determined by a competitive RIA (23).

After 52 weeks of treatment or after an additional 12week treatment-free period, the animals were killed by an intravenous injection of pentobarbitone sodium and immediate exsanguination.

A full macroscopic examination of all tissues and organs was performed. During necropsy, epididymides, prostate, seminal vesicles and testes were weighed before fixation. Samples of epididymides, prostate and seminal vesicles were fixed in $4 \%$ buffered formaldehyde solution and testes were fixed in Bouin's fluid. In addition, samples of the above organs were fixed in 5\% glutaraldehyde in $0.067 \mathrm{~mol} / \mathrm{l}$ sodium cacodylate buffer (pH 7.4). The formaldehyde-fixed tissue was embedded in paraffin wax, sectioned and stained with haematoxylin and eosin (HE). The Bouin-fixed testes were embedded in methacrylate (Historesin) and the glutaraldehyde-fixed samples were embedded in Epon. Sections were stained with HE, periodic acid-Schiff or toludine blue (Epon sections) and examined under the light microscope.

Statistical evaluation of body weight, body weight change and organ weights was performed with Bartlett's test for homogeneity of variances, followed by a rank transformation and Bartlett's test in case of heterogeneity only ( $P<0.05$, equivalent to $95 \%$ probability). For hormonal data and sperm analysis a rank transformation was performed, followed by Bartlett's test for homogeneity of variances. For homogeneous data, the one-way analysis of variance (ANOVA) was performed. In the event of significant results for the ANOVA $(P<0.05$, equivalent to $95 \%$ probability), Dunnett's two-tailed $t$-test was used to compare each treated group against the control group. In the case of heterogeneity of the ranktransformed data, Kruskal-Wallis test was performed together with Wilcoxon rank-sum test to compare each treated group against the control group.

The statistical evaluation was performed with the standard software package SAS (Statistical Analysis System) release 6.04. Data are expressed as means \pm s.E.M.

\section{Results}

One low-dose male was killed in extremis on day 210 of the study due to chronic enteritis. This was considered to be a spontaneous disease and not related to the treatment with rhGH. In the further analysis this animal was not accounted for.

Body weight was within historical control data for the animals in all groups, although the group 3 animals

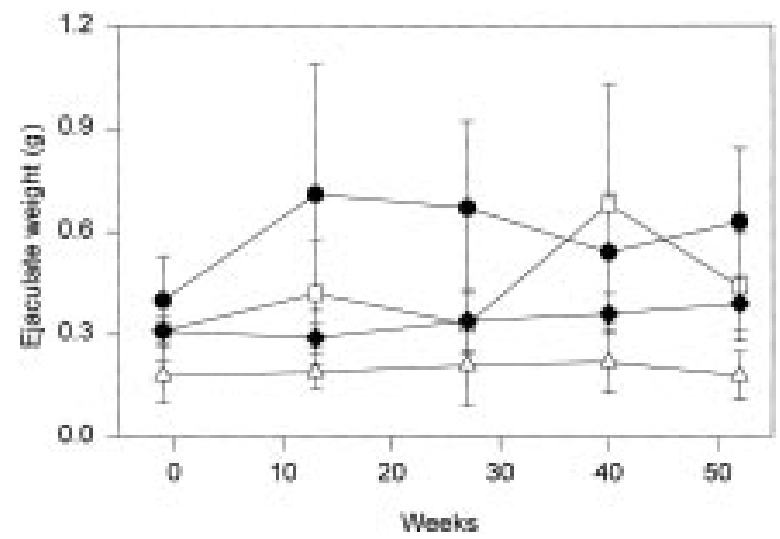

Figure 1 Ejaculate weight $(\mathrm{g})$ during the treatment period in controls $(\bullet)$, animals treated with $0.4 \mathrm{IU} / \mathrm{kg}$ per day $(\square), 2 \mathrm{IU} / \mathrm{kg}$ per day $(\triangle)$, or $10 \mathrm{IU} / \mathrm{kg}$ per day $(\diamond)$.

(2 IU/kg per day) showed the lowest mean body weight throughout the experimental period and including the pre-test period. There was no effect on ejaculate weight, sperm motility and morphology (Figs 1 and 2), weight of genital organs (Table 1), sperm count or testicular volume throughout the treatment period, or during the
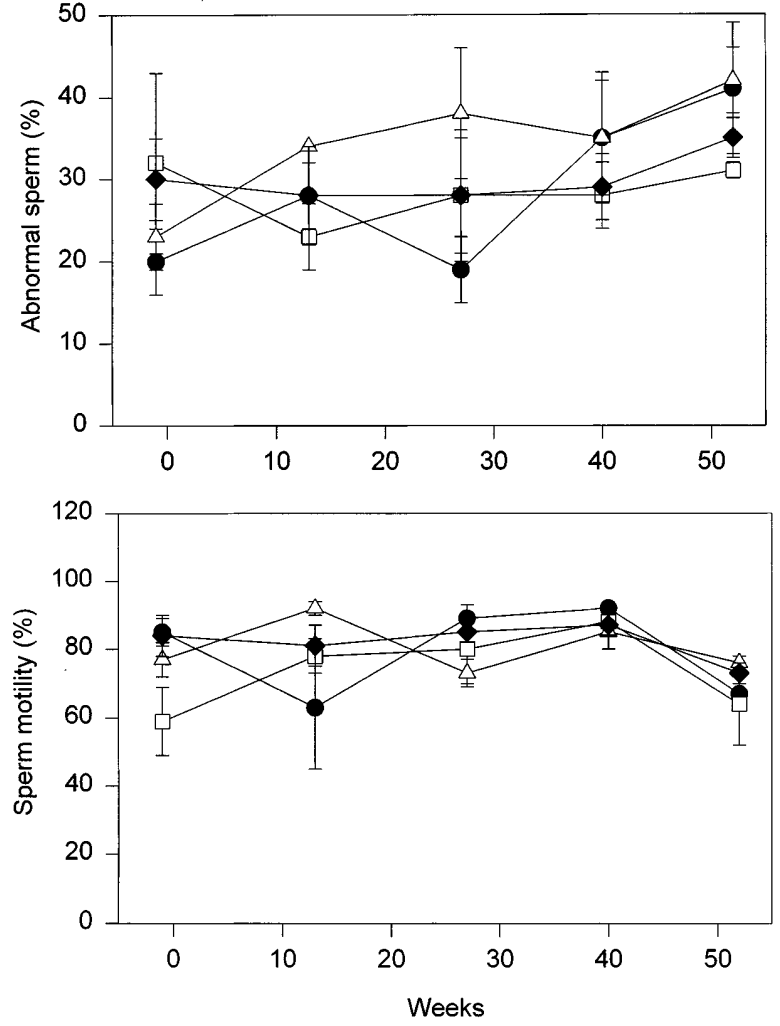

Figure 2 Percentage of abnormal sperm (upper panel) and sperm motility (lower panel) during the treatment period in controls $(\bullet)$, animals treated with $0.4 \mathrm{IU} / \mathrm{kg}$ per day $(\square), 2 \mathrm{IU} / \mathrm{kg}$ per day $(\triangle)$, or $10 \mathrm{IU} / \mathrm{kg}$ per day $(\bullet)$. 
Table 1 Group mean organ weight (g) at necropsy.

\begin{tabular}{|c|c|c|c|c|c|c|c|}
\hline \multirow[b]{2}{*}{ Organ } & & \multicolumn{4}{|c|}{ At completion of treatment } & \multicolumn{2}{|c|}{ After recovery period } \\
\hline & & $\begin{array}{c}\text { Group } 1 \\
(0 \mathrm{IU} / \mathrm{kg} \text { per day })\end{array}$ & $\begin{array}{c}\text { Group } 2 \\
(0.4 \mathrm{IU} / \mathrm{kg} \text { per day })\end{array}$ & $\begin{array}{c}\text { Group } 3 \\
(2 \mathrm{IU} / \mathrm{kg} \text { per day })\end{array}$ & $\begin{array}{c}\text { Group } 4 \\
\text { (10 IU/kg per day) }\end{array}$ & $\begin{array}{c}\text { Group } 1 \\
(0 \mathrm{IU} / \mathrm{kg} \text { per day })\end{array}$ & $\begin{array}{c}\text { Group } 4 \\
(10 \mathrm{IU} / \mathrm{kg} \text { per day) }\end{array}$ \\
\hline Testes & $\begin{array}{l}\text { Mean } \\
\text { S.E.M. } \\
n\end{array}$ & $\begin{array}{c}35.53 \\
3.39 \\
5\end{array}$ & $\begin{array}{c}32.74 \\
6.93 \\
4\end{array}$ & $\begin{array}{c}21.51 \\
2.23 \\
5\end{array}$ & $\begin{array}{c}35.46 \\
3.67 \\
5\end{array}$ & $\begin{array}{l}45.68 \\
- \\
2\end{array}$ & $\begin{array}{l}46.38 \\
- \\
2\end{array}$ \\
\hline Epididymides & $\begin{array}{l}\text { Mean } \\
\text { S.E.M } \\
n\end{array}$ & $\begin{array}{l}7.34 \\
1.24 \\
5\end{array}$ & $\begin{array}{l}8.69 \\
0.57 \\
4\end{array}$ & $\begin{array}{l}5.27 \\
0.85 \\
5\end{array}$ & $\begin{array}{l}8.15 \\
1.33 \\
5\end{array}$ & $\begin{array}{l}8.28 \\
- \\
2\end{array}$ & $\begin{array}{l}7.20 \\
- \\
2\end{array}$ \\
\hline Seminal vesicles & $\begin{array}{l}\text { Mean } \\
\text { S.E.M } \\
n\end{array}$ & $\begin{array}{l}9.94 \\
1.53 \\
5\end{array}$ & $\begin{array}{c}10.44 \\
2.16 \\
4\end{array}$ & $\begin{array}{l}5.92 \\
1.44 \\
5\end{array}$ & $\begin{array}{l}9.23 \\
1.04 \\
5\end{array}$ & $\begin{array}{c}10.36 \\
- \\
2\end{array}$ & $\begin{array}{l}8.29 \\
- \\
2\end{array}$ \\
\hline Prostate & $\begin{array}{l}\text { Mean } \\
\text { S.E.M } \\
n\end{array}$ & $\begin{array}{l}1.79 \\
0.12 \\
5\end{array}$ & $\begin{array}{l}2.17 \\
0.27 \\
4\end{array}$ & $\begin{array}{l}1.61 \\
0.19 \\
5\end{array}$ & $\begin{array}{l}1.87 \\
0.20 \\
5\end{array}$ & $\begin{array}{l}2.07 \\
- \\
2\end{array}$ & $\begin{array}{l}2.15 \\
- \\
2\end{array}$ \\
\hline
\end{tabular}

recovery period (Fig. 3). Already on day 5 and throughout the treatment period, serum IGF-I levels showed a dose-related increase in all dose groups (Fig. 4). At the end of the recovery period the IGF-I levels were comparable to predose values (not shown).
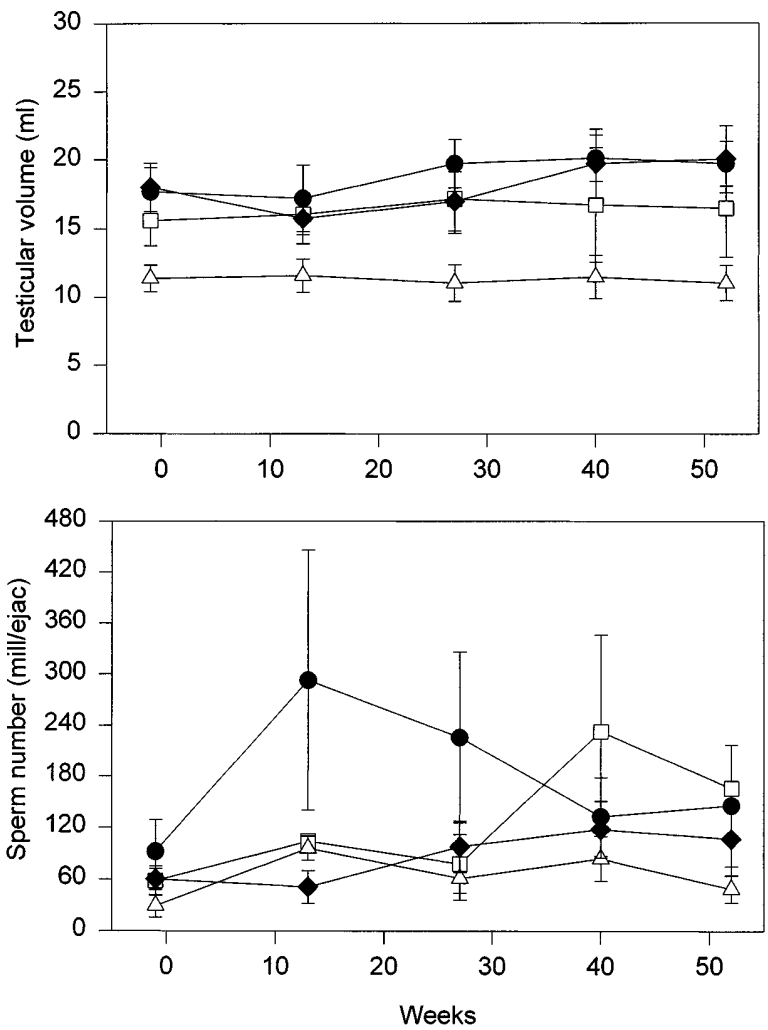

Figure 3 Testicular volume (ml) (upper panel) and sperm number (million (mill)/ejaculate) (lower panel) during the treatment period in controls $(\bullet)$, animals treated with $0.4 \mathrm{lU} / \mathrm{kg}$ per day $(\square), 2 \mathrm{IU} / \mathrm{kg}$ per day $(\triangle)$, or $10 \mathrm{IU} / \mathrm{kg}$ per day $(\diamond)$.
Although there was a great individual variation in PRL serum concentrations, statistically significant reductions $(P<0.05)$ were found in the high-dose group from week 14 and throughout the treatment period (Fig. 5). PRL levels were normalised at the end of the treatment-free period. There were large variations in serum testosterone and LH levels in all groups (Fig. 6). However, the values were considered to be within the normal limits of the background data for this species $(24,25,26) \mathrm{and} /$ or in the range of the pre-test data. FSH levels in serum collected at different time-points were under the detection limit in many cases. However, for those samples that had measurable values (two to four/group) there were no apparent treatment-related effects on serum FSH throughout the experimental period (data not shown). No significant amounts of rhGH antibodies appeared in treated animals. Microscopic examination of the testicular biopsies, collected

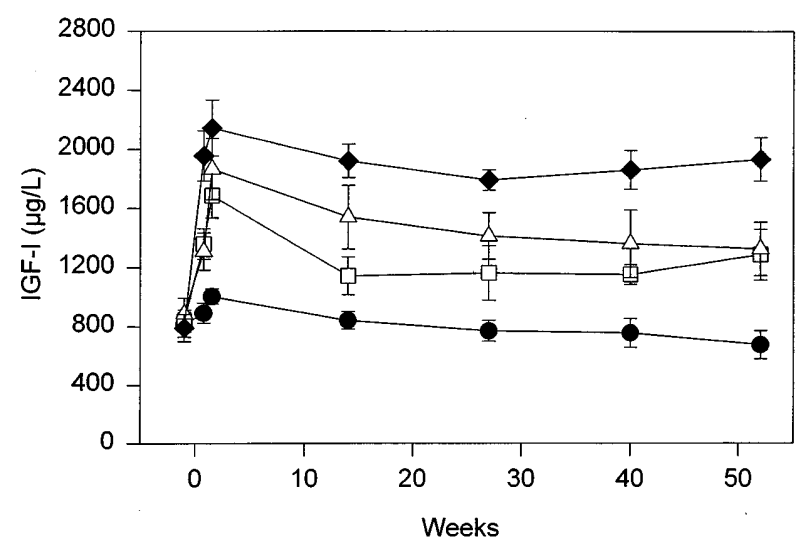

Figure 4 Serum IGF-I levels $(\mu \mathrm{g} / \mathrm{l})$ during the treatment period in controls $(\bullet)$, animals treated with $0.4 \mathrm{IU} / \mathrm{kg}$ per day $(\square), 2 \mathrm{IU} / \mathrm{kg}$ per day $(\triangle)$, or $10 \mathrm{IU} / \mathrm{kg}$ per day $(\diamond)$. 


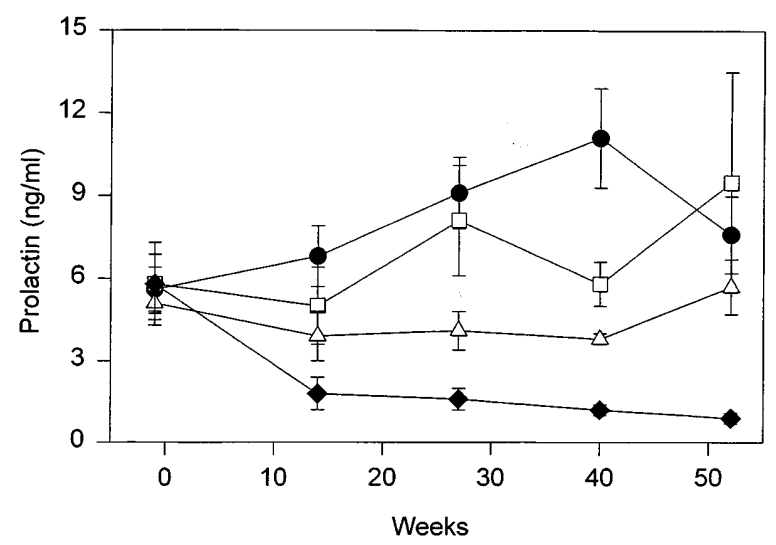

Figure 5 Serum PRL levels $(\mathrm{ng} / \mathrm{ml})$ during the treatment period in controls $(\bullet)$, animals treated with $0.4 \mathrm{IU} / \mathrm{kg}$ per day $(\square), 2 \mathrm{IU} / \mathrm{kg}$ per day $(\triangle)$, or $10 \mathrm{IU} / \mathrm{kg}$ per day $(\bullet)$.

before the treatment started, revealed normal spermatogenesis in the examined animals. Treatment with rhGH did not induce any morphological testicular changes as judged from biopsies taken after 15 days or organ samples collected after 52 weeks of treatment or after the 12-week recovery period (Fig. 7).
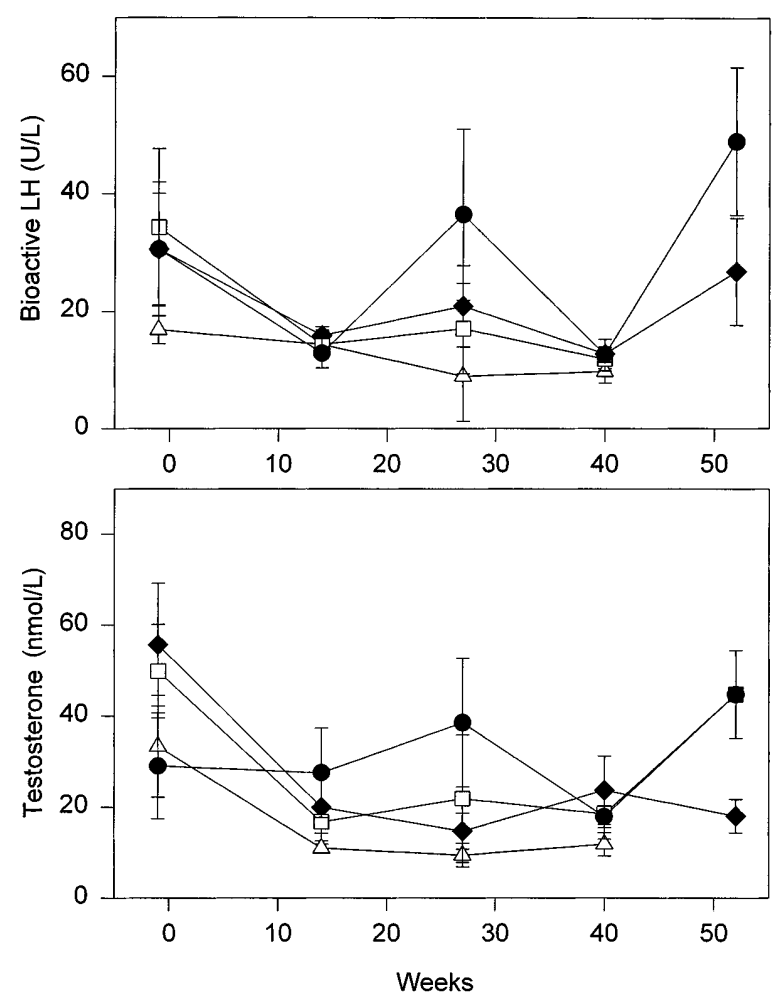

Figure 6 Serum bioactive LH levels (U/I) (upper panel) and testosterone levels (nmol/l) (lower panel) during the complete treatment period for controls $(\bullet)$, and animals treated with $10 \mathrm{IU} / \mathrm{kg}$ per day $(\diamond)$, or for the first 40 weeks of treatment for animals treated with $0.4 \mathrm{IU} / \mathrm{kg}$ per day $(\square)$ or $2 \mathrm{IU} / \mathrm{kg}$ per day $(\triangle)$.

\section{Discussion}

In earlier preclinical safety studies in dogs where high doses of hGH have been administered for 20-28 days, severe testicular changes have been observed in primary and secondary spermatocytes and spermatids (14). The changes were accompanied by reduced plasma levels of $\mathrm{LH}$, testosterone and PRL and resembled those seen after hypophysectomy or treatment with gonadotrophinreleasing hormone (GnRH) agonists. In the present study, serum testosterone levels were highly variable. Although a trend towards lower values might be apparent in GH-exposed animals, this is likely a matter of chance rather than a true biological effect for the following considerations: lack of corresponding changes in the secretion of bioactive LH and lack of effect on the testosterone-dependent accessory organs (prostate, epididymis, seminal vesicles). Cynomolgus monkeys lack a clear-cut reproductive seasonality in captivity $(27,28)$ and under outdoor conditions (29) so it is improbable that the testosterone variations reflect such an effect. Reduced PRL serum levels were seen in the monkeys. The low serum PRL concentrations did not cause any alterations in testicular function as judged from testicular weight, size, morphology and sperm analyses. The reason for the reduction of PRL levels is not known, but since hGH has a lactogenic activity (30), a negative feedback on PRL production is possible at the high doses given to the monkeys. We are, however, not aware of hGH binding to monkey or dog PRL receptors. PRL has a role in spermatogenesis in seasonal breeders, rodents and man $(31,32)$. In several species which breed throughout the year, PRL enhances gonadal responsiveness to gonadotrophin stimulation by increasing the number of LH receptors (33). In men, a 4-week-long bromocriptine-induced hypoprolactinaemia significantly reduced the maximal response of plasma testosterone to human chorionic gonadotrophin stimulation (34). To our knowledge, the effects of hypoprolactinaemia on testicular function in the cynomolgus monkey have not been described.

The reason for the difference between the cynomolgus monkey and the beagle dog in effect on spermatogenesis after hGH administration is not known. The most probable explanation is that hGH is structurally different from canine GH and thereby does not act biologically as $\mathrm{GH}$ in the dog. A comparison of the canine and human $\mathrm{GH}$ renders $68.3 \%$ identity in amino acid sequence. By contrast, macaque GH has $96.3 \%$ identity (35). In toxicity studies with $\mathrm{GH}$ in the dog, porcine GH (structurally similar to canine $\mathrm{GH}$ ) has been administered in doses of $0.025,0.1$ and $1.0 \mathrm{IU} / \mathrm{kg}$ per day to dogs for 14 weeks, without any adverse effects on testes or other male reproductive organs being reported (36). However, increased pituitary weights were recorded and quantitative analysis of immunostained cells in pars distalis showed an increase in the absolute volume of GH-, PRL- and adrenocorticotrophin-containing cells. 
Figure 7 Photomicrograph from testis from a onkey treated with $\mathrm{rhGH}$ (10 IU/kg per day) for 52 weeks. Spermatogenesis appears normal. HE stain; $\times 830$.

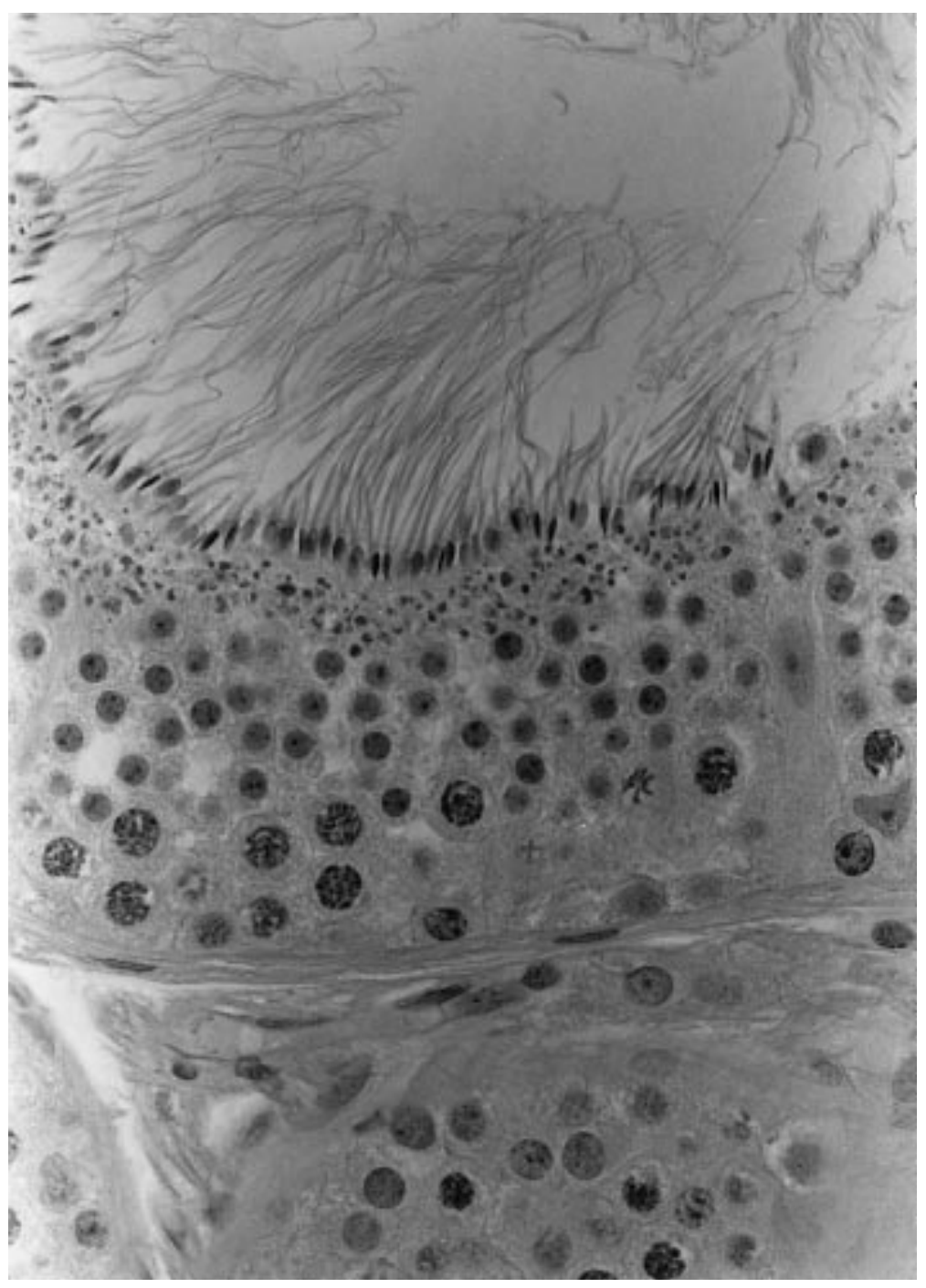

However, effects on serum/plasma levels of PRL were not measured or reported (37). Plasma levels of PRL were found to be unaffected in beagles after administration of a non-peptidyl secretagogue which induced increased levels of GH (38).

Another explanation for the species difference is that spermatogenesis in the dog seems to be far more vulnerable than in the cynomolgus monkey. This is evident from studies using GnRH agonists which induced complete testicular involution within about 3-4 weeks (39), whereas the achievement of such an effect requires a few months in macaque monkeys (40).

Serum IGF-I levels showed a dose-dependent increase seen already on day 5 of treatment and throughout the treatment period. At the end of the recovery period, IGF-I serum concentrations were comparable to those seen predose. The IGF-I response is considered to be due to the exogenous hGH administered (41), and shows that the hGH was biologically active during the study period.

Neither decreased nor increased spermatogenesis was observed. It should be noted, however, that the monkeys used were adult normal, non-GH-deficient animals. The results are in accordance with those presented in an earlier study where Crawford \& Handelsman (42) showed that in prepubertal baboons without $\mathrm{GH}$ deficiency, treatment with neither GH nor IGF-I was able to enhance the inhibin response to FSH.

To conclude, administration of high doses of hGH to adult male cynomolgus monkeys for 1 year caused a dose-dependent increase of IGF-I serum levels throughout the study and a reduction of PRL serum levels from week 14 in monkeys given $10 \mathrm{IU} / \mathrm{kg}$ per day. Both changes were reversible upon cessation of treatment. Testicular parameters were unaffected at all doses. 


\section{Acknowledgements}

Appreciation is expressed to Mrs Ingrid Sandström for preparing the slides and to Professor Leif Plöen, Professor Martin Ritzén and Dr Hans-Erik Johansson for scientific discussions while planning and performing this study.

\section{References}

1 Shoham Z, Zelel Y \& Jacobs HS. The role of growth hormone in male infertility. Clinical Endocrinology 199441 1-5.

2 Sheikolislam BM \& Stempfel RS Jr. Hereditary isolated somatotropin deficiency: effects of human growth hormone administration. Pediatrics $197249362-374$.

3 Laron Z, Mimouni F \& Pertzelan A. Effect of human growth hormone therapy on penile and testicular size in boys with isolated growth hormone deficiency: first year of treatment. Israel Journal of Medical Sciences 198319 338-344.

4 Laron Z, Sarel R \& Pertzelan A. Puberty in Laron type dwarfism. European Journal of Pediatrics 1980134 79-83.

5 Matsushima M, Kuroda K, Shirai M, Ando K, Sugisaki T \& Noguchi T. Spermatogenesis in Snell dwarf, little and congenitally hypothyroid mice. International Journal of Andrology $19869132-$ 140.

6 Swanlund DJ, N'Diaye MR, Loseth KJ, Pryor JL \& Crabo BG. Diverse testicular responses to exogenous growth hormone and follicle-stimulating hormone in prepubertal boars. Biology of Reproduction 199553 749-757.

7 Pedersen SA, Jørgensen JO, Christiansen JS, Jensen S, Jelnæs JE \& Skakkebæk NE. Growth hormone and reproduction: reduced semen quality in men previously treated for growth hormone deficiency. In International Symposium on Hormonal Regulation of Growth, pp 274-282. Eds H Frisch \& MO Thorner. Vienna: Raven Press, 1989.

8 Shoham Z, Conway GS, Ostergaard H, Lahlou N, Bouchard P \& Jacobs HS. Cotreatment with growth hormone for induction of spermatogenesis in patients with hypogonadotropic hypogonadism. Fertility and Sterility 199257 1044-1051.

9 Kulin HE \& Santen RJ. Endocrinology of puberty in men. In Regulatory Mechanisms of Male Reproductive Physiology, pp 175190. Eds CH Spilman, TJ Lobi \& KT Kirton. Amsterdam: Excerpta Medica, 1976.

10 Spiteri-Grech J \& Nieschlag E. The role of growth hormone and insulin-like growth factor I in the regulation of male reproductive function. Hormone Research 199238 (Suppl 1) 22-27.

11 Zachmann M. Interrelations between growth hormone and sex hormones: physiology and therapeutic consequences. Hormone Research 199238 (Suppl 1) 1-8.

12 Jørgensen KD, Svendsen O, Greenough RJ, Kallesen T, Goburdhun R, Skydsgaard K, Finch J, Dinesen B \& Nilsson P. Biosynthetic human growth hormone: Subchronic toxicity studies in rats and monkeys. Pharmacology and Toxicology 198862 329-333.

13 Flodh H, Johansson H-E, Jönsson M \& Ekvärn S. General toxicity in rats of biosynthetic and pituitary human growth hormone. In Hormone Drugs. Proceedings of the FDA-USP Workshop on Drug and Reference Standards for Insulins, Somatropins, and Thyroid-axis Hormones, pp 327-334. Ed WM Heller. Bethesda, MD: Pharmacopeial Conventions Inc. 1982.

14 Sjögren I, Jönsson M, Madej A, Johansson H-E \& Plöen L. Effects of very high doses of human growth hormone $(\mathrm{hGH})$ in the male dog. Andrologia $19983037-42$.

15 Weinbauer GF \& Nieschlag E. Hormonal control of spermatogenesis. In Molecular Biology of the Male Reproductive System, pp 99-142. Ed DM de Kretser. New York: Academic Press, 1993.

16 Korte R, Vogel F, Bee W \& Osterburg I. The use of the non-human primate in reproduction toxicology. In Teratologie, pp 167-191. Eds R Korte. J Fanghänel \& R Gossrau. Berlin: de Gruyter, 1993.
17 World Health Organisation. Laboratory Manual for the Examination of Human Semen and Semen-Cervical Mucus Interaction. Cambridge: Cambridge University Press, 1987.

18 Weinbauer GF, Surmann FJ, Akhtar FB, Shah GV, Vickery BH \& Nieschlag E. Reversible inhibition of testicular function by a gonadotropin hormone-releasing antagonist in monkeys (Macaca fascicularis). Fertility and Sterility 198442 906-914.

19 Hult C, Mendel-Hartvig I, Vangbo B \& Öhlander C. A radioimmunoassay (RIA) for quantification of IGF-1 in acidethanol extracted serum using truncated IGF-1 as tracer. A validation report. Kabi Pharmacia Internal Report 9296572 (on file) 1992

20 Chandolia RK. Weinbauer GF, Simoni M, Behre HM \& Nieschlag E. Comparative effects of chronic administration of the non-steroidal antiandrogen flutamide and Casodex on the reproductive system of the adult male rat. Acta Endocrinologica 1991125 547555 .

21 Khurshid S, Weinbauer GF \& Nieschlag E. Effects of administration of testosterone and gonadotrophin-releasing hormone (GnRH) antagonist on basal and GnRH-stimulated gonadotrophin secretion in orchidectomized monkeys. Journal of Endocrinology $1991129363-370$.

22 Wickings EJ, Qazi MH \& Nieschlag E. Determination of biologically active LH in the serum of male rhesus monkeys (Macaca mulatta). Journal of Reproduction and Fertility 197957 497-504.

23 Larsson T. Determination of antibodies to human growth hormone (hGH) by radioimmunoassay (RIA). Kabi Pharmacia Internal Method of Analysis A 405-03 (on file) 1992.

24 Weinbauer GF, Surmann FJ \& Nieschlag E. Suppression of spermatogenesis in a nonhuman primate (Macaca fascicularis) by concomitant gonadotropin-releasing hormone antagonist and testosterone treatment. Acta Endocrinologica 1987114 138-146.

25 Weinbauer GF, Khurshid S, Fingscheidt U \& Nieschlag E. Sustained inhibition of sperm production and inhibin secretion induced by a gonadotrophin-releasing hormone antagonist and delayed testosterone substitution in non-human primates (Macaca fascicularis). Journal of Endocrinology 1989123 303-310.

26 Weinbauer GF, Simoni M, Hutchison JS \& Nieschlag E. Pharmacokinetics and pharmacodynamics of recombinant and urinary human FSH in the male monkey (Macaca fascicularis). Journal of Endocrinology 1994141 113-121.

27 Honjo S, Cho F, Fujinara T, Yoshioka Y, Masuko Y, Kurihara K, Yabe M \& Noguchi Y. Breeding of cynomolgus monkeys through successive generations by indoor cage systems. Japanese Journal of Medical Science 197831 301-310.

28 Klein PM, Kramer MF \& de Rooij DG. Testicular development of Macaca irus after birth. International Journal of Andrology 19836 $25-43$.

29 Kavanagh M \& Laursen E. Breeding seasonality among longtailed macaques, Macaca fascicularis, in peninsular Malaysia. International Journal of Primatology 19875 17-29.

30 Kleinberg DL \& Todd J. Evidence that human growth hormone is a potent lactogen in primates. Journal of Clinical Endocrinology and Metabolism 198051 1009-1013.

31 Bartke A. Prolactin and the physiological regulation of the mammalian testis. In The Testis in Normal and Infertile Men, pp 367-378. Eds P Troen \& HR Nankin. New York: Raven Press, 1977.

32 Bartke A, Klemcke $\mathrm{H}$ \& Matt K. Effects of physiological and abnormally elevated prolactin levels on the pituitary-testicular axis. Medical Biology $198563264-272$.

33 Bartke A \& Dalterio S. Effects of prolactin on the sensitivity of the testis to LH. Biology of Reproduction 197615 90-93.

34 Oseko F, Nakano A \& Morikawa K. Effects of chronic bromocriptineinduced hypoprolactinemia on plasma testosterone responses to human chorionic gonadotropin stimulation in normal men. Urology-andrology. 199155 355-357.

35 Benson DA, Boguski MS, Lipman DJ, Ostell J \& Ouellette BF. GenBank. Nucleic Acids Research 199826 1-7. 
36 Prahalada S, Stabinski LG, Chen HY, Morrisey RE, De Burlet G, Holder D, Patrick DH, Peter CP \& van Zwieten MJ. Pharmacological and toxicological effects of chronic porcine growth hormone administration in dogs. Toxicologic Pathology 199826 $185-200$.

37 Laroque P, Molon-Noblot S, Prahalada S, Stabinski LG, Hoe C-M, Peter CP, Duprat P, Chen HY \& van Zwieten MJ. Morphological changes in the pituitary gland in dogs chronically exposed to exogenous growth hormone. Toxicologic Pathology $199826201-$ 206.

38 Jacks T, Hickey G, Judith F, Taylor J, Chen H, Krupa D, Feeney W, Schoen W, Ok D, Fisher M, Wyvratt M \& Smith R. Effects o acute and repeated intravenous administration of l-692,585, a novel non-peptidyl growth-hormone secretagogue, on plasma growth-hormone, IGF-1, ACTH, cortisol, prolactin, insulin and thyroxine levels in beagles. Journal of Endocrinology 1994143 399-406.

39 Paramo RM, Renton JP, Ferguson JM \& Concannon PW. Effect of medroxyprogesterone acetate or gonadotrophin-releasing hormone agonist on suppression of spermatogenesis in the dog (Canis familiaris). Journal of Reproduction and Fertility 1993 Suppl 47 387-397.

40 Weinbauer GF \& Nieschlag E. Reversibility of GnRH agonistinduced inhibition of testicular function: Comparison between rat, monkey and man. In LHRH Agonists in Oncology, pp 91-103. Ed HG Höffken. Berlin: Springer Verlag, 1988.

41 Wallis M. Regulation of somatomedin production by growth hormone. In Hormones and their Actions, part II, pp 275-276. Eds BA Cooke, RJB King \& HJ van der Molen. Amsterdam: Elsevier Science Publishers B.V., 1988.

42 Crawford BA \& Handelsman DJ. Recombinant growth hormone and insulin-like growth factor I do not alter gonadotrophin stimulation of the baboon testis in vivo. European Journal of Endocrinology $1994131405-412$.

Received 31 August 1998

Accepted 14 January 1999 